Dubnitsky V.I., Fedulova S.O., Tyutyunnik O.V., Hotinets A.O.

\title{
THE CONDITIONS OF MODERNIZING THE ECONOMIC SAFETY OF NATIONAL ECONOMY IN THE CONTEXT OF PROVISION OF ENERGY SAFETY
}

\author{
Ukrainian State University of Chemical Technology, Dnipro, Ukraine
}

\begin{abstract}
The paper presents the conceptual scheme of functioning of the wholesale market of electric energy in the framework of interaction of participants of the megacity system of the Ukrainian fuel and energy complex. The model of the organizational and economical mechanism for ensuring the energy security of the national economy is shown. The explanation to the model of functioning and use of fuel and energy resources of Ukraine is given. The approach to organization of the process of rational use of fuel and energy resources is proposed. The model of the hierarchical structure of energy security is shown. The preconditions for creation and functioning in the system of fuel and energy of industrial cluster associations as one of the components of the appearance of energy security of the national economy are revealed. Also presented is the conceptual structure of the cluster association «Eco-Energo», which is used in the framework of the formation of a program of energy supply in the context of energy security of the fuel and energy complex of Ukraine. The proposed conceptual scheme of functioning of the wholesale electricity market within the framework of the energy supply process among the participants of the mega-network system of Ukrainian fuel and energy complex. The model of organizational and economic mechanism for providing energy security of the economy is presented. The development of the organization of the process of rational use of fuel and enegetical resources in the framework of providing energy security is carried out.
\end{abstract}

Keywords: economic security, energy security, fuel and energy complex, networking, national economy, energy cluster association, regulatory economy, network interaction.

DOI: $10.32434 / 2415-3974-2019-9-1-24-34$

\section{Problem statement}

Industry is one of the leading branches of the national economy, which ensures economic growth of the country, social and economic standard of living of the population. Depending on the state and level of industry's efficiency, the state is considered an economically developed or economically backward country. At the present stage of Ukraine's development, in a context of reorientation of the model of socio-economic development of the country and its regions or branches, in accordance with the challenges of globalization, the industry becomes a key factor in the growth of the economy's efficiency.

Ukraine has always been an industrially developed state precisely because of its strong industrial potential, the development of industrial activities, the export of industrial products and the production of goods for industrial and technical purposes. This leads to the increased interest of society, in particular scientists and practitioners, in the ability of industry to play the role of technological leader and producer of factors of strategic economic development, not only the country as a whole, but also its regions and industries.

In view of the above, the strategic aspect of increasing the efficiency of using the industrial and technical potential of the industry, justifying and choosing the appropriate strategy, developing the strategic goals of the industry or region is of particular importance. The objective process of absorption of theoretical and applied researches, which provide further development of theoretical foundations and improvement of the estimation of the preconditions for the emergence of energy clusters in the energy sector of the fuel and energy complex of Ukraine, the scientific, theoretical and practical significance of these issues, predetermined the choice of this study

(C) Dubnitsky V.I., Fedulova S.O., Tyutyunnik O.V., Hotinets A.O., 2019 
and its relevance.

Theoretical principles of the effectiveness of network forms of interaction in the electric power sector of the TEC of Ukraine in the framework of the formation of a system for ensuring economic and energy security of the economy in the conditions of market transformations at the level of the industry were considered in the fundamental works of I.M. Mazur [1], V.G. Dersky [2], O.I. Chernyak [3], A.K. Shidlovsky and M.P. Kivalka [4], V.I. Muntiana [5], T.I. Salashenko [6], S.O. Makovetsky [7], N.N. Volkova [9], V.I. Dubnitsky [9], O.Yu. Kudrin [10].

The purpose of the work is to study the peculiarities of the development of network associations of the electricity sector of the fuel and energy complex of Ukraine and to identify the necessary conditions for the economic and energy security of the national economy.

\section{Statement of the mean material}

Practice shows that in the conditions of world markets the most important indicator of the activity of industrial network associations - clusters is the provision of high innovation and investment competitiveness of their products, therefore cluster development of territorial-sectoral and integration industrial associations in the conditions of one country is one of the characteristic features modern innovation economy, especially within the industrial regions in cooperation with the avant-garde industries of the economic complex, including the fuel and energy complex of Ukraine.

Important and actual tendencies of regional economic development are the principles:

- resource balance of growth of the industrialindustrial complex of the region, including energy;

- systematic improvement of the structure of the economic territorial-branch complex of the region in the direction of increasing the share of resourcesaving ecologically safe technologies;

- rational allocation of productive forces in the system of «big city - the periphery of the region»;

- provision of the possibility of placing scienceintensive industries;

- processes of economic network clusterization.

Methodical approaches to the formation and interaction of market networks in territorial-branch associations in order to deepen the sectoral specialization and effectively use the achievements of innovation research at the level of the industrial complex of the industrial region at the expense of the methods of the network investment project as the basis of network interaction of the production network structures will enable, as evidenced the best practices of the electricity sector of the EU member states, will significantly increase the competitiveness of the region. The criteria determining the direction of clustering the enterprises of the electric power sector on the basis of the industry's opportunities in the conditions of the industrial region, in the context of the marketing system of innovations used for the purpose of energy saving, will enable the effective development of territorial-branch associations.

Analysis of researches on the use of a cluster approach to the development of enterprises of the territorial-sectoral complex, among which N.N. Volkoy [8], V.I. Dubnitsky [9], I.M. Mazur [1], testifies to the lack of experience in the practical functioning of enterprises in cluster structures. Taking into account the fact that none of the domestic industries of the economy is capable of functioning without the energy sector products of the country's fuel and energy complex, it can be argued that development based on a cluster approach, first of all, fuel and energy complex enterprises within the industrial regions and increasing its potential, is one of the decisive directions for the improvement of regional and national economies.

Today, the domestic energy industry has a high level of power losses, low efficiency of operation, and low level of use of energy saving technologies. However, only the awareness of the need to create network cluster associations will enable the development of clustering and fully utilize the competitive advantages of clusters. Several varieties of energy clusters have been created in the world today: heat and power, power generation, fuel and energy; clusters of renewable energy sources, clusters of non-traditional renewable energy. Any of these varieties of clusters creates the ability to provide energy savings.

The electricity cluster is defined as an integrated group of economically and technologically interconnected and interacting enterprises and organizations of various forms of ownership that provide a synergistic effect as a result of the introduction of economic activity and the implementation of socio-economic relations, provided with service, repair and engineering services, a fundamental research and educational base in a single information and technology control circuit.

A bright example of the effective implementation of energy clusters is the Finnish cluster «Cleantech». Finland consumes a very large amount of energy due to energy-intensive industries, cold climates and large distances. At the same time, the country's own energy resources are limited (hydro energy, wood and peat). Finland imports $70 \%$ of the total consumer energy in the country. In order to meet national needs, for several decades, one of the main priorities of Finland's energy strategy is the development of an efficient energy system. The research and development carried out over the past decades, as well as the continuous modernization of 
the energy system, have raised Finnish energy technologies to world standards. The increased use of renewable energy, combined heat and power production (endeavor), and the intensification of energy conservation help Finland to meet its international commitments to reduce atmospheric emissions.

Most Finnish companies operating in the Cleantech cluster are small and medium businesses. Many are not well-known, but they are world-class companies in their sector. The goal of creating a cluster is to unite their efforts. At present, the trade turnover of about two thousand Finnish companies operating in the sector of clean technologies, according to expert estimates, is up to 20 billion. euro. Energy-related clusters are usually formed where «breakthrough» advancements in the field of energy saving and production technology are being or are expected to be made, and the further entry into new market niches.

Figure 1 shows the structural scheme of the cluster association of the Eco-Energo cluster within the fuel and energy complex of Ukraine.

For the fuel and energy complex (FEC) as the leading branch of the economic complex of Ukraine, the issue of increasing competitiveness and adaptation in the conditions of transformation of the national and regional economy is one of the most urgent. As the world experience shows, significant changes in the organization of efficient production at the regional level contribute to the creation of territorial-sectoral and integrational industrial associations of networktype clusters.

The fuel and energy complex (FEC) of the state is a complex organizational and economic system, consisting of a set of mutually beneficial industrial-network structures. The complexity of the investigated complex as a system consists in the fact that each of the selected structural elements is a system of lower level of the hierarchy, while individual systems need to be considered as independent subsystems operating within the framework of network interaction. Allocated elements of the fuel and energy complex of the state are not homogeneous, as they differ in their functions, as well as the type and degree of interconnection power within the megacity system (FEC), and have their own functional and organizational structure.

The fuel and energy complex of Ukraine is an organizational system that operates on the principles of network diversified interaction. Prominent specialists in the field of management of industrial network systems VN Spitsnadel, I.M. Mazur, allocate such properties of fuel economy of the state.

1. The presence of structural connections (a set of structural connections of the studied system within the sectoral hierarchy).

2. The presence of relationships of interaction, relationships and subordination. The relationships between the elements of the system (given the functions performed by the system itself and the aggregate subsystems) can also be regarded as internal-functional relationships and relations of the system. The high degree of interdependence between the elements of the fuel and energy complex of the state indicated the impossibility of fully functioning of any of its elements separately, that is, the fuel and energy complex system is complex and hierarchical (subordinate). Effective (balanced) functioning of this bundled-diversified structure (SDS), ie its elements, and in general, the RMS is possible on the basis of their interaction. This is a sign of the existence of integrated system properties.

3. Connectivity of the processes of development

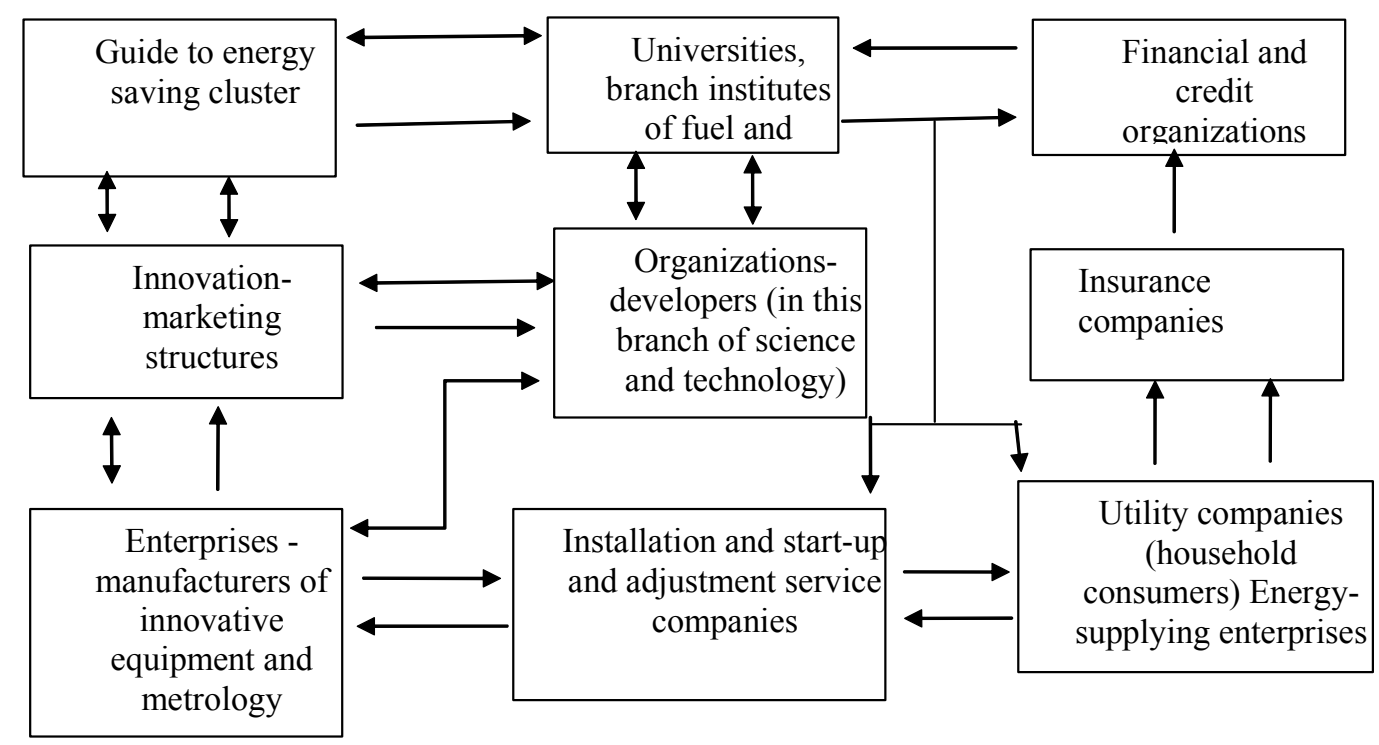

Fig. 1. The block diagram of the cluster association of the cluster «Eco-Energo» 
of the fuel and energy complex in general and its elements in particular. The gradual transition to alternative energy sources, due to limited fuel resources and environmental requirements, provides for the possibility of qualitative transformation of the fuel and energy complex. The reduction of the role of a purely fuel area (subsystem of the Fuel and Energy Complex) will be accompanied by an increase in the value of enterprises and organizations that use alternative energy sources, and, consequently, the development of the electric power subsystem of the FEC [1].

4. Availability within the framework of this organization of system subsystems of individual enterprises, which include, on the principles of network interaction, lower levels of enterprises operating within the framework of cluster interaction.

I.A Franchuk identifies in the fuel and energy complex of Ukraine such subsystems that are transformed into a period of mixed economy: oil and gas, coal, and electricity [11]. Allocated subsystems have different levels of complexity and homogeneity, differ in structure and place in the fuel and energy complex. At the same time, the author highlights the higher degree of activity of the fuel and energy complex compared to the activity of its elements (subsystems). He argues that this degree is a sign of the organization of this system, given the state's energy security. So, in his opinion, the initiative of the elements of the fuel and energy complex is clearly regulated by the governing bodies on the basis of the interests of the whole system of fuel and energy or national, regional economy in general.

Certain activity of the elements, which is contrary to the governing bodies, is probably due to changes in the environment of the system element and is not purposeful. In our opinion, it should be noted that the fuel and energy complex of Ukraine is characterized by high level of regulation and control by state institutions (for example, NCEE). The influence of the state economic policy is felt by every point of the studied system.

Firstly, by legislative means: legislative regulation is aimed at implementing the strategy of development of national and regional economies and fuel economy of the state as a whole, as well as on the safety of the production elements of subsystems,
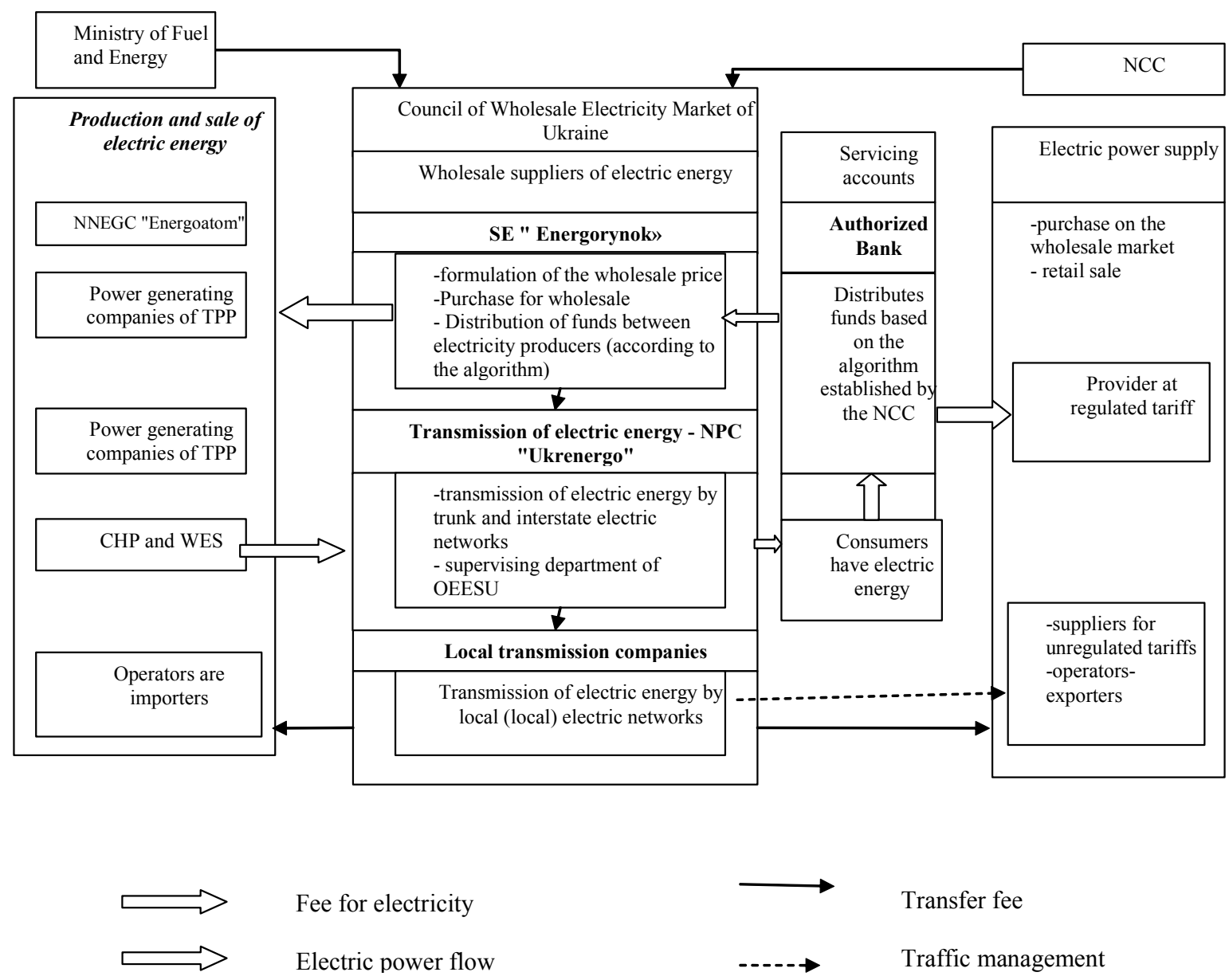

Fig. 2. Conceptual scheme of functioning of the wholesale market of electric energy in the framework of interaction of participants of the megaynet system of the Ukrainian fuel and energy complex 
because the need for technical security in the fuel and energy complex is directly related to national security. This regulation applies to each point of the subsystem regardless of ownership.

Second, within the framework of executive powers, the management of enterprises of the complex applies to enterprises that are wholly or partly owned by the state. The scheme of functioning of the wholesale electricity market in the framework of the interaction of participants of the megaynetwork system is shown in Figure 2. During the transition to market relations, the state itself creates the environment of the economic entities that, within their systems and large network structures, having cluster initiatives, want to optimize their activities in the new environment. At the same time, the state directly simply regulates the activities of actors. The nature of the functioning and development of the fuel and energy complex of Ukraine is determined by the combined effect of its elements, as well as the influence of other systems of the national economy.

The energy strategy of Ukraine until 2030 is developed on the basis of the laws of Ukraine «On Electric Power» [12], «On Measures to Ensure the Functioning of Fuel and Energy Complex» [13], as well as «Energy Strategy of Ukraine until 2030 and the Future Perspective». In our opinion, it is necessary to agree with the position of the majority of experts of the Fuel and Energy Complex and scientists of the National Academy of Sciences of Ukraine, who consider it necessary to ensure the monitoring of the energy system and periodic refinement (adjustment) of the scope and timing of the work envisaged by the strategy, taking into account the dynamics of prices for fuel and energy resources in the world and the country. , achievement of scientific and technological progress, realization of state and regional programs of economic development and other factors.

The implementation of the energy strategy of Ukraine until 2030 should ensure that the country becomes an influential and active participant in international energy relations, including through participation in international, interstate (for example, within the framework of the «Euroregions») formations in energy projects. The effectiveness of state regulation of the development of electricity is largely determined by the structure of the industry and the forms of competition.

Proceeding from the realities of the existence of a two-tier market of electricity (wholesale and retail), one can project the stages of transition from monopoly to competitive, which influences on the nature and direction of interaction (Fig. 2).

Today, the transformation of the models of economies of the leading countries of the world into a resource-oriented type, which determines the principles of the formation of energy policy, is traced. Global energy security is not limited to the availability of energy resources in the world market and the sustainability of their supply. Its goal was to ensure equal access to fuel and energy resources in sufficient amount for the development of economic entities of all countries of the world, to limit environmental pollution and to preserve the resource base for future generations.

The volume of fuel and energy consumption (FER) in developing countries is increasing at the expense of increasing living standards of the population. Increasing dependence on the energy resources of national economies necessitates the substantiation of managerial decisions in the energy sector and the implementation of measures to improve energy security across all strategic levels.

The concept of «energy security» is often encountered in modern scientific writings, but there is no single interpretation of the essence and structure;

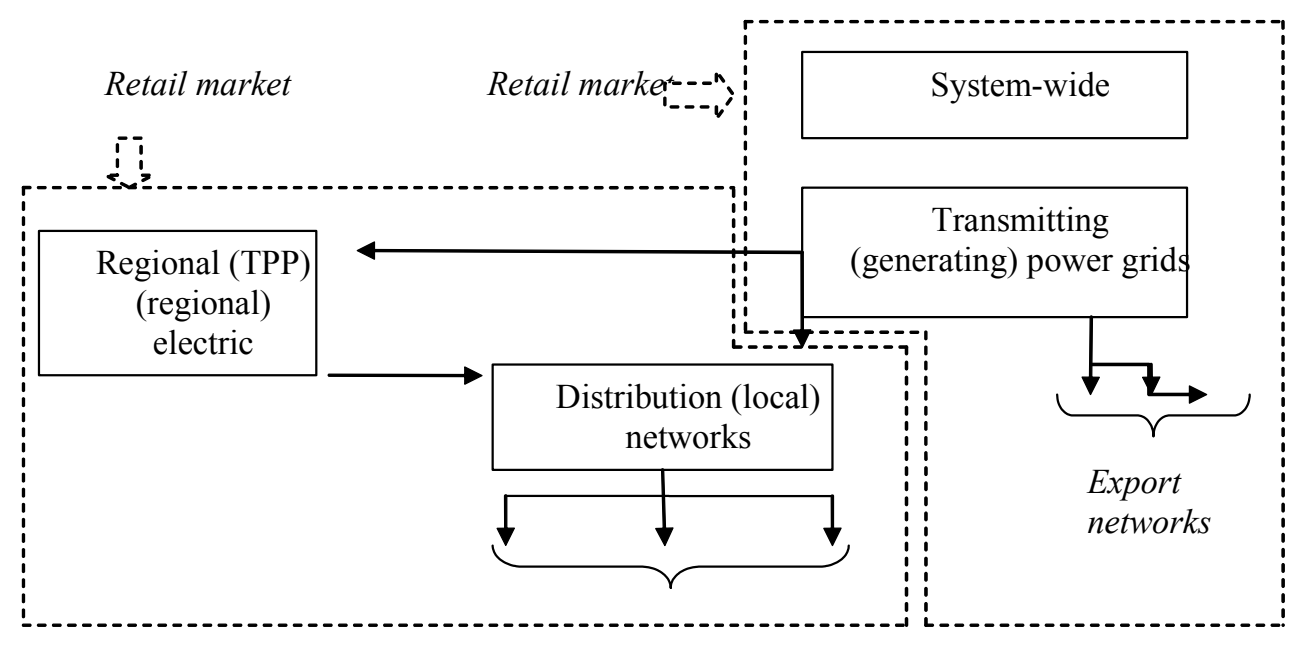

Fig. 3. The technical structure of the power system and the network of wholesale and retail energy markets of Ukraine 
a large number of questions regarding regulation, forecasting and assessment of the state of energy security of the national economy have been neglected, therefore, it is advisable to continue the research in a definite direction. Of particular relevance is the search for forms and methods for providing management decisions with reliable information, which will reflect the impact of threats to the energy security of the economy of the country, region, industry, enterprises.

Formation of methodological support for the assessment of the economic and energy security of the economy in Ukraine is at the initial stage of the development of conceptual foundations, which requires the settlement of practical and theoretical provisions in the existing regulatory environment. In our opinion, the development of a system of indicators of energy security deserves special attention, which should provide a quantitative, comparative and relative assessment of its state and changes under the influence of certain factors that influence the provision of interests in the energy sector. Fig. 4 presents the conceptual model of the organizational and economic mechanism for ensuring the energy security of the national economy, developed by I.M. Mazur [1, p.15].

Essential characteristics of the latter will be reflected in the indicators in the methodology for assessing the level of energy security and analysis of the impact of trends in the change of threats [1, p.7]. Among the recent studies in this direction should be noted works I.M. Mazur [1], E.V. Chlobistova [14], T.O. Zhuravleva [15], V.I. Muntiana [5], S.I. Sukhina [16].
To implement the Energy Strategy of Ukraine, an effective mechanism for ensuring the energy security of the national economy should be built. We agree with I.M. Mazur, that this mechanism will include economic, administrative, financial, legislative and regulatory forms, levers, incentives and methods of regulation. At the same time, the effectiveness of the implementation of the organizational and economic mechanism of security is significantly dependent on financial provision in the general experience of financial resources. Fig. 5 shows the model of the formation and use of fuel and energy resources of Ukraine [1, p.84].

From our point of view, the model for the formation and use of fuel and energy resources is a combination of theoretical and applied conditions, regularities, dependencies, principles and directions of development that will enable to substantiate the optimal combination of different elements of the energy system. Economic systems that arise in the process of forming, distributing and consuming primary fuel and energy resources are conditioned by the nature of the country's economic system and ownership relations of resources and factors of production.

Fig. 6. shows the organization of the process of rational use of fuel and energy resources.

The essence of rational use of fuel and energy resources (FER) is to achieve the maximum efficiency of their spending for the existing level of development of technology and technology and simultaneous reduction of technogenic impact on the environment. Energy saving is an activity (organizational, scientific, practical) aimed at the

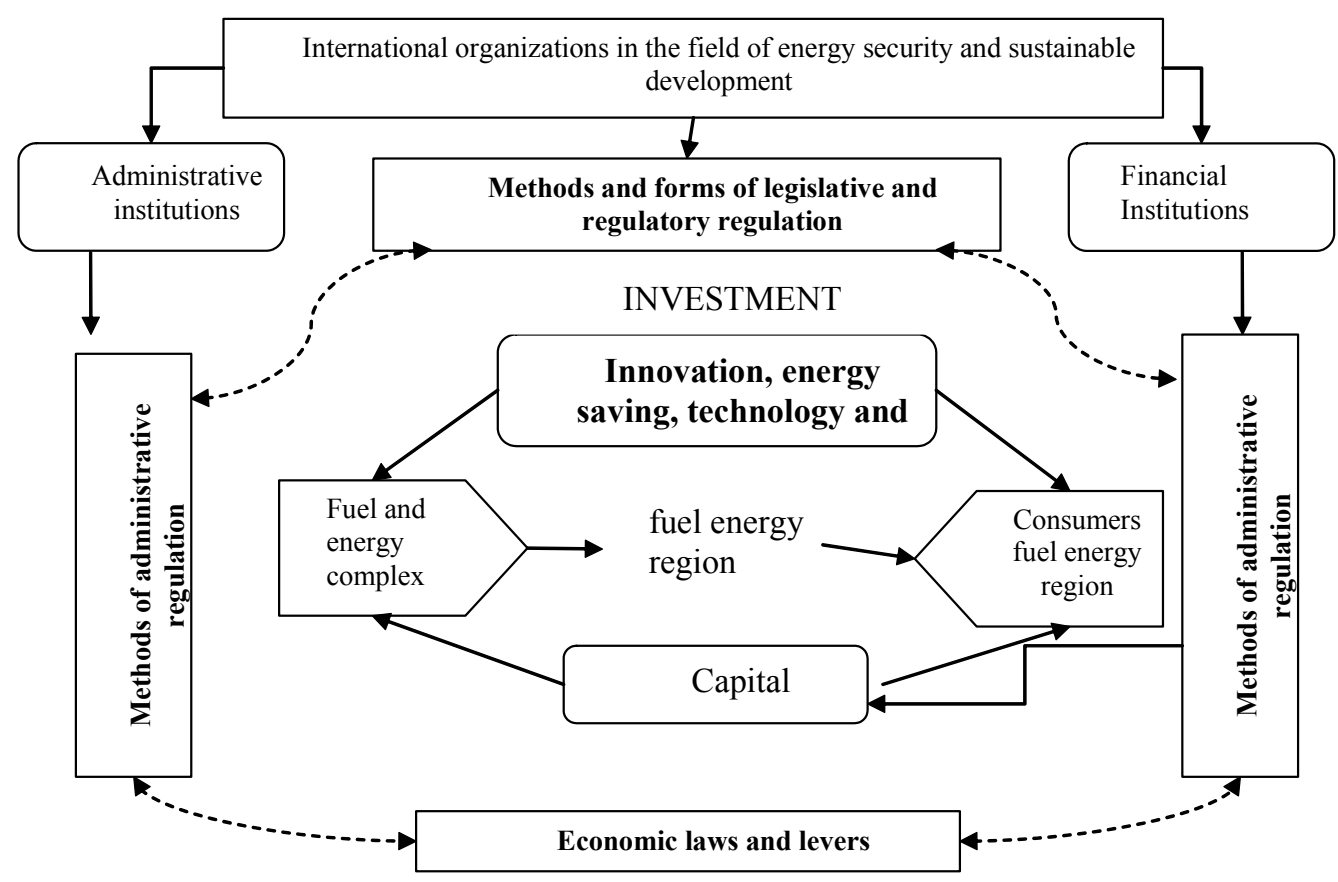

Fig. 4. Model of organizational and economic mechanism for ensuring the energy security of the national economy 


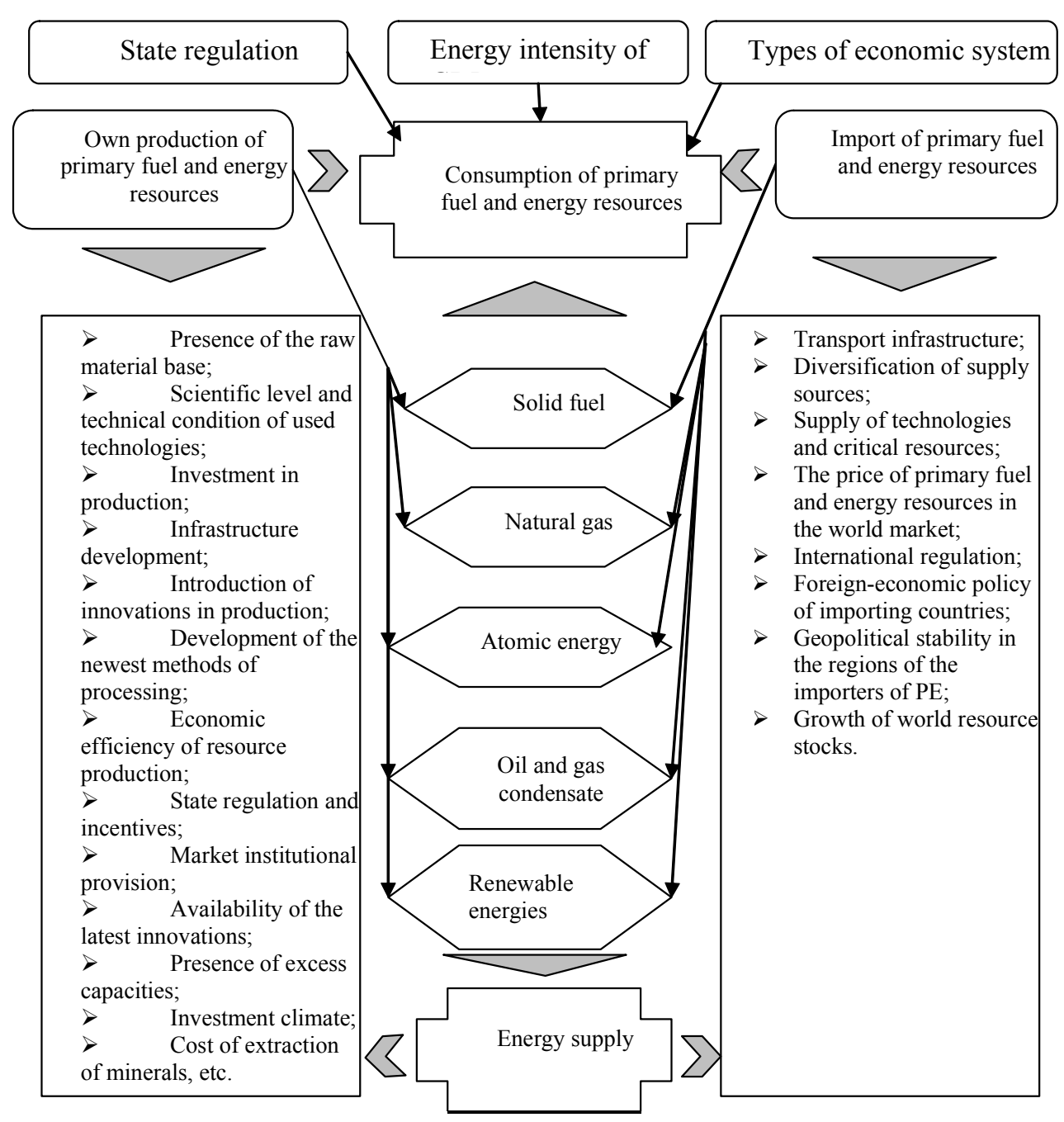

Fig. 5. Model of formation and use of fuel and energy resources of Ukraine

rational use and economical use of primary and transformed energy and natural energy resources in the national economy, which is implemented using technical, economic and legal methods. (see fig. 7).

In addition, the stability of economic development reflects economic security, which characterizes the state of the economy, which guarantees the protection of the interests of the individual, society, state, social orientation of politics, even under adverse conditions of development of internal and external processes. It is considered that economic security is determined by the contribution of all its components, which are presented in Fig. 7.

The term «energy security» is widely used by experts in the field of energy and energy management, used by researchers in normative documents and scientific publications. We restrict the definition of energy security to a purely economic aspect, neglecting the social and fiscal sphere: the energy security of a market economy is the provision of an economy of FER value, which, on the one hand, is a possible process of reproduction in the sectors of the fuel and energy complex, and on the other hand, when in the main sectors of the national economy positive value added is created. Figure 8 presents a model of the hierarchical structure of energy security [1, p.27].

\section{Conclusions}

Ukraine has one of the world's largest energy saving potential. The technical energy saving potential estimated in 2030 will be 198.1 million tons and the structural potential is 120.3 million tons of power. One of the promising directions of the integrated solution of energy security problems and energy efficiency improvement of industrial enterprises is the creation of energy clusters, which involves the association on the voluntary and mutually beneficial basis of existing manufacturers and consumers of energy carriers, suppliers, network and management structures and others that form a common strategy for the development of industrial enterprises within a certain region and country as a whole. $[13,14]$. 


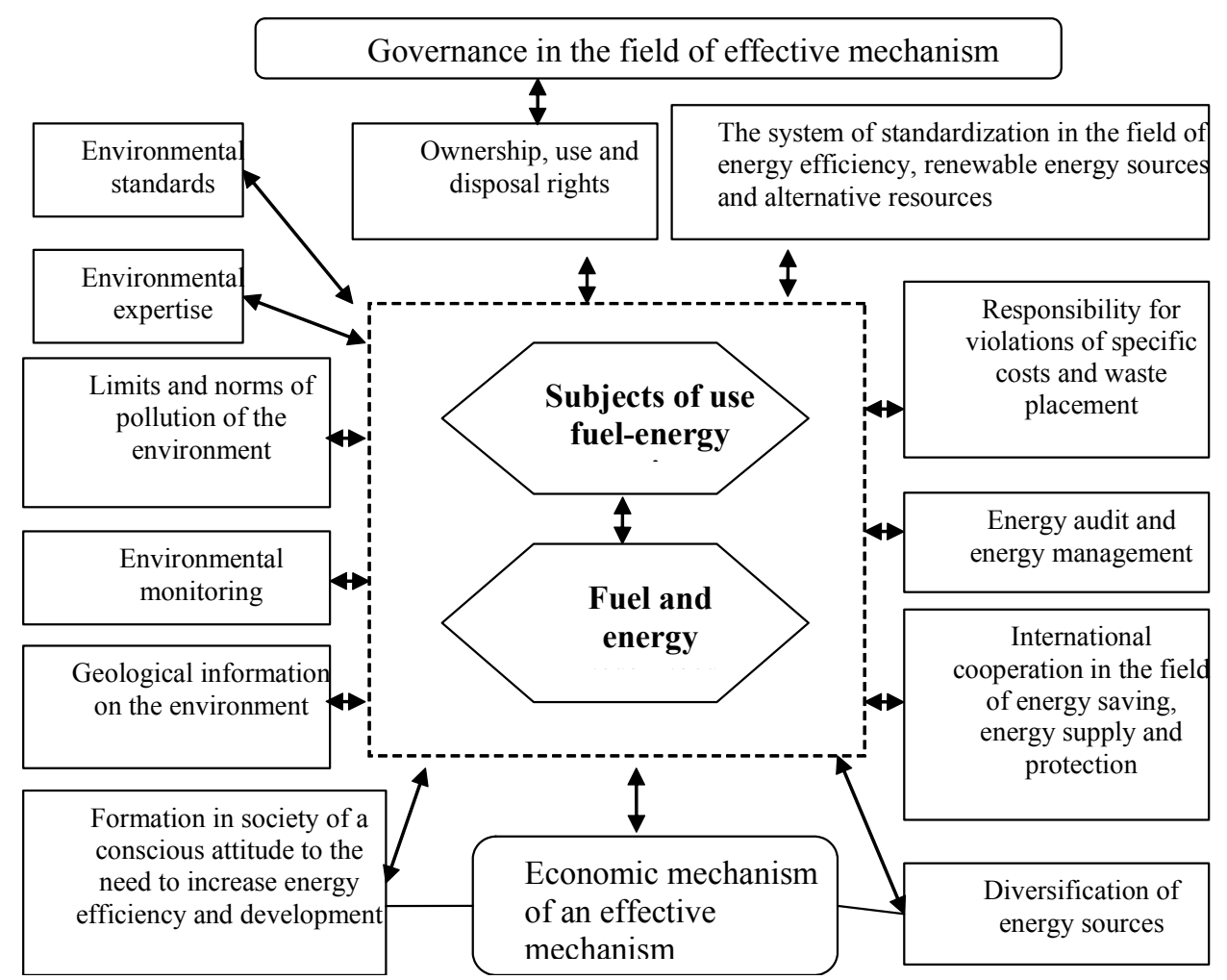

Fig. 6. Organization of the process of rational use of fuel and energy resources.

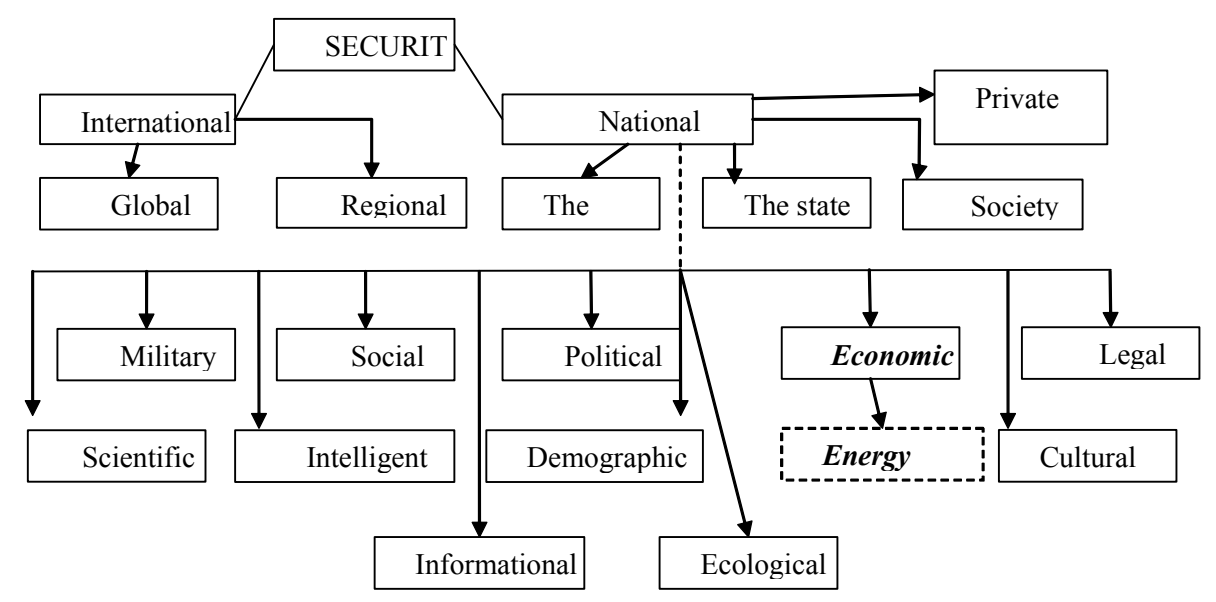

Fig. 7. Energy security as a sphere in the security system of the country, territory or region

The algorithm of creating an industrial cluster within the framework of an important branch for Ukraine is an interdependent set of procedures and tasks for the formation of an economic entity that functions on the basis of the corresponding production structure, financial and credit relations of its participants and the management system, which represent a sequence of logically related stages, namely: preparatory; study of market conditions for cluster formation and approval of institutional and organizational principles of partnership; assessment of intentions and specification of cooperation strategies and cluster interaction; formation of criteria of efficiency and control system of the effectiveness of cluster interaction and definition of the plan of joint actions of cluster participants. [15]

The main purpose of the creation of an industrial cluster within the electricity sector of the Ukrainian Fuel and Energy Complex is to create a long-term cooperative, long-term partnership aimed at the formation and implementation of joint programs in the industrial market of energy resources. The main point is the presentation of a set of sector cluster initiatives, an organizational and economic mechanism for the formation of a target industrial network association, the development of which is to 


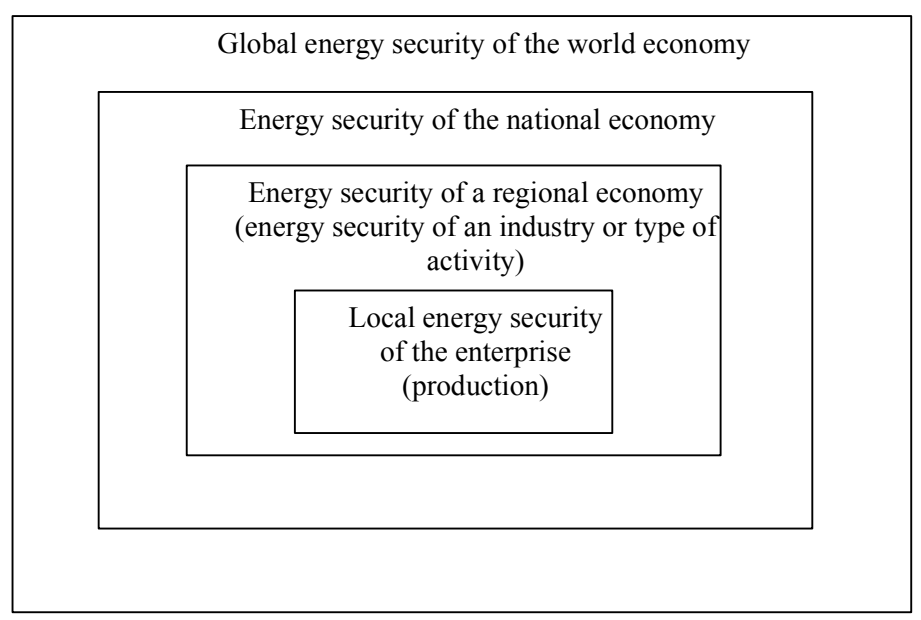

Fig. 8. Model of the hierarchical structure of energy security

substantiate a set of methodological and methodological provisions that provide solutions to its procedures and tasks.

The clusters in the electric power industry are usually formed where the «breakthroughs» in energy saving and production technologies are being implemented or are expected to be realized and the further entry into new «market prices».

Our basic conclusion is that only the cooperation of science, technology and production will contribute to the development of the Ukrainian fuel and energy complex and create competitive advantages in the context of network interaction.

\section{REFERECES}

1. Mazur I.M. Organizational and Economic Mechanism for Ensuring the Energy Security of the National Economy: monograph. - Ivano-Frankivsk: NAIP, 2014. $-618 \mathrm{p}$.

2. Derzsky V.G. Market reform in Ukrainian electricity industry and pricing // Energy saving. Power engineering. Energy audit. - 2012. - No. 11. - P. 13-29.

3. Chernyak O.I. Modeling of economic security on macroand mesorovnykh // Modeling of economic security: state, region, enterprise: monograph. - Kharkiv: INZHEK, 2006. - 204 p.

4. Fuel and energy complex of Ukraine on the threshold of the third millennium / per coalition. Ed. AK Shidlovsky, MP Kovalka. - K.: UES, 2001. -398 p.

5. Muntian VI Economic security of Ukraine: monograph. - K.: KVIT, 1999. - 464 p.

6. Salashenko T.I. Increasing the energy efficiency of the industrial region: choosing the priority directions of the energy economy by type of industrial activity // Economic forum. 2001. - № 4. [Electronic resource]. - Access mode: https: // nbuv.gov.ua/j-pdf/NpKntu_e_2012_21_18.pdf.
7. Makovetsky S.O. Economic strategy: formation of new production systems: introduction of network structures in Ukraine // Management of the economy of transition: Sat. scientific degree Yield 1 / NAS of Ukraine. Inton econ. pro-sty: redkol.N.G. Chumachenko, IP Buleev, VI Lyashenko - Donetsk, 2008. P.364-378.

8. Volkova N.N, T.V. Sakhno. Industrial clusters. - Poltava: ASMI, 2005. - 243 p.

9. Dubnitsky V.I. New industrial-industrial systems and their influence on the efficiency of the transformation of the region's economy: collective monograph // «Transformation of the industrial complex of the region: problems of development management» / in common. Ed. YOU. Dubnitsky, IP Buleyeva - Donetsk: South-East, 2008. - . P.135-174.

10. Kudrin $O . Y u$. Industrial potential of the region: formation, evaluation, and strategy: monograph. - Lugansk: Nouillod, 2014. $-456 \mathrm{p}$.

11. Franchuk I.A. Analysis of the structure of electricity markets, differentiated by types of activities and directions of development of their state regulation // Economy and the state. - 2008 - № 1. - P.57-63.

12. Law of Ukraine «On Electricity» dated 16.10 .1997 No. 55/97 - BP // BBP. - 1998. - №1. - Article 1.

13. Law of Ukraine «On measures aimed at ensuring the sustainable functioning of enterprises of the fuel and energy complex» of 23.06.2005 № 2711-IV // BBP. - 2015. - No. 33. - St.430.

14. Sustainable development and ecological safety of society: theory, methodology, practice / For sciences. Ed. Ye.V. Hobbies - Simferopol: Arial, 2011. - 598 p.

15. Priority directions of regional policy in the economic sphere (development of branches and regional production, budget regulation and financing): monograph. - For zag.red. THEN. Zhuravleva - Pavlograd: Art-Synthesis - 2014. - 363 p.

Received 24.10.2018

Reviewer: Doct. of Econ. Sc., Ass. Prof. Harmider L.D. 


\section{УМОВИ МОДЕРНІЗАЦІЇ ЕКОНОМІЧНОЇ БЕЗПЕКИ НАЦІОНАЛЬНОЇ ЕКОНОМІКИ В КОНТЕКСТІ ЗАБЕЗПЕЧЕННЯ ЕНЕРГЕТИЧНОЇ БЕЗПЕКИ}

Дубницький В.І., Федулова С.О., Тютюнник О.В., Хотинець А.О.

У статті представлено концептуальну схему функціонування оптового ринку електроенергії в рамках взаємодії учасників мегаполісної системи українського паливно-енергетичного комплексу. Показано модель організаційно-економічного механізму забезпечення енергетичної безпеки національної економіки. Наведено пояснення до моделі функціонування та використання паливно-енергетичних ресурсів України. Запропоновано підхід до організації процесу раціонального використання паливно-енергетичних ресурсів. Показана модель ієрархічної структури енергетичної безпеки. Виявлено передумови для створення та функціонування в системі паливно-енергетичного комплексу промислових кластерних об'єднань як однієї з складових появи енергетичної безпеки національної економіки. Також представлена концептуальна структура кластерного об'єднання «Еко-Енерго», яке використовується в рамках формування програми енергозабезпечення в контексті енергетичної безпеки паливно-енергетичного комплексу України. Запропонована концептуальна схема функціонування оптового ринку електроенергії в рамках процесу енергопостачання серед учасників мега-мережевої системи українського паливно-енергетичного комплексу. Представлена модель організаційно-економічного механізму забезпечення енергетичної безпеки економіки. Проводиться розвиток організації процесу раціонального використання паливно-енергетичних ресурсів в рамках забезпечення енергетичної безпеки.

Ключові слова: економічна безпека, енергетична безпека, паливно-енергетичний комплекс, мережа, національна економіка, енергетична кластерна асоціація, регуляторна економіка, мережева взаємодія.

\section{УСЛОВИЯ МОДЕРНИЗАЦИИ ЭКОНОМИЧЕСКОЙ БЕЗОПАСНОСТИ НАЦИОНАЛЬНОЙ ЭКОНОМИКИ В КОНТЕКСТЕ ОБЕСПЕЧЕНИЯ ЭНЕРГЕТИЧЕСКОЙ БЕЗОПАСНОСТИ}

Дубницкий В.И., Федулова С.А., Тютюнник О.В., Хотинец А.О. В статье представлена концептуальная схема функционирования оптового рынка электрической энергии в рамках взаимодействия участников мегаполисной системы украинского топливно-энергетического комплекса. Показана модель организационно-экономического механизма обеспечения энергетической безопасности национальной экономики. Дано оббяснение модели функционирования и использования топливно-энергетических ресурсов Украины. Предложен подход к организации процесса рационального использования топливно-энергетических ресурсов. Показана модель иерархической структуры энергетической безопасности. Выявлены предпосылки для создания и функционирования в системе топливно-энергетического комплекса отраслевых кластерных объединений как одной из составляющих возникновения энергетической безопасности национальной экономики. Также представлена концептуальная структура кластерного объединения «Эко-Энерго», которое используется в рамках формирования программы энергоснабжения в контексте энергетической безопасности топливно-энергетического комплекса Украины. Предложена концептуальная схема функционирования оптового рынка электроэнергии в рамках процесса энергоснабжения среди участников мегасетевой системы украинского топливно-энергетического комплекса. Представлена модель организационно-экономического механизма обеспечения энергетической безопасности экономики. Осуществлена разработка организации процесса рационального использования топливно-энергетических ресурсов в рамках обеспечения энергетической безопасности.
Ключевые слова: экономическая безопасность, энергетическая безопасность, топливно-энергетический комплекс, сетевое взаимодействие, национальная экономика, объединение энергетических кластеров, регуляторная экономика, сетевое взаимодействие.

\section{THE CONDITIONS OF MODERNIZING THE ECONOMIC SAFETY OF NATIONAL ECONOMY IN THE CONTEXT OF PROVISION OF ENERGY SAFETY}

Dubnitsky V.I., Fedulova S.O. ", Tyutyunnik O.V., Hotinets A.O. Ukrainian State University of Chemical Technology, Dnipro, Ukraine

\section{* e-mail: sveta_fedulova@ukr.net}

The paper presents the conceptual scheme of functioning of the wholesale market of electric energy in the framework of interaction of participants of the megacity system of the Ukrainian fuel and energy complex. The model of the organizational and economical mechanism for ensuring the energy security of the national economy is shown. The explanation to the model of functioning and use of fuel and energy resources of Ukraine is given. The approach to organization of the process of rational use of fuel and energy resources is proposed. The model of the hierarchical structure of energy security is shown. The preconditions for creation and functioning in the system of fuel and energy of industrial cluster associations as one of the components of the appearance of energy security of the national economy are revealed. Also presented is the conceptual structure of the cluster association "Eco-Energo», which is used in the framework of the formation of a program of energy supply in the context of energy security of the fuel and energy complex of Ukraine. The proposed conceptual scheme of functioning of the wholesale electricity market within the framework of the energy supply process among the participants of the mega-network system of Ukrainian fuel and energy complex. The model of organizational and economic mechanism for providing energy security of the economy is presented. The development of the organization of the process of rational use of fuel and enegetical resources in the framework of providing energy security is carried out.

Keywords: economic security, energy security, fuel and energy complex, networking, national economy, energy cluster association, regulatory economy, network interaction.

Refereces

1. Mazur I.M. Organizational and Economic Mechanism for Ensuring the Energy Security of the National Economy: [monograph] / I. Mazur. - Ivano-Frankivsk: NAIP, 2014. - 618 p.

2. Derzsky V.G. Market reform in Ukrainian electricity industry and pricing / VG Derzsky // Energy saving. Power engineering. Energy audit. - 2012. - No. 11. - P. 13-29.

3. Chernyak O.I. Modeling of economic security on macro- and mesorovnykh / O.I. Chernyak // Modeling of economic security: state, region, enterprise: [monograph]. - Kharkiv: INZHEK, 2006. - 204 p.

4. Fuel and energy complex of Ukraine on the threshold of the third millennium / per coalition. Ed. AK Shidlovsky, MP Kovalka - K.: UES, 2001. - 398 p.

5. Muntian VI Economic security of Ukraine: [monograph] / V.I. Muntian - K .: KVIT, 1999. - 464 p.

6. Salashenko T.I. Increasing the energy efficiency of the industrial region: choosing the priority directions of the energy economy by type of industrial activity / T.I. Salashenko // Economic forum. - 2001 №4 [Electronic resource]. - Access mode: https: //nbuv.gov.ua/j-pdf/NpKntu_e_2012_21_18.pdf. 
7. Makovetsky S.O. Economic strategy: formation of new production systems: introduction of network structures in Ukraine / SO Makovetsky // Management of the economy of transition: Sat. scientific degree Yield 1 / NAS of Ukraine. Inton econ. prosty: redkol.N.G. Chumachenko, IP Buleev, VI Lyashenko Donetsk, 2008, - P. 364-378.

8. Volkova N.N. Industrial clusters / N. N. Volkova, T. V. Sakhno. - Poltava: ASMI, 2005. - 243 p.

9. Dubnitsky V.I. New industrial-industrial systems and their influence on the efficiency of the transformation of the region's economy / collective monograph // «Transformation of the industrial complex of the region: problems of development management» / in common. Ed. YOU. Dubnitsky, IP Buleyeva - Donetsk: South-East, 2008. -. Pp. 135-174.

10. Kudrin O.Yu. Industrial potential of the region: formation, evaluation, and strategy: [monograph] / O.Yu. Kudrin Lugansk: Nouillod, 2014. - 456 pp.

11. Franchuk I.A. Analysis of the structure of electricity markets, differentiated by types of activities and directions of development of their state regulation / I.A. Franchuk // Economy and the state. - 2008 - №1. - p. 57-63.

12. Law of Ukraine «On Electricity» dated 16.10.1997 No. 55/97 - BP // BBP. -1998. - №1. - Article 1

13. Law of Ukraine «On measures aimed at ensuring the sustainable functioning of enterprises of the fuel and energy complex» of 23.06.2005 № 2711-IV // BBP. - 2015. - No. 33. St.430. 